Paweł Petrzak, Kazimierz Kowalski, Magdalena Rozmus-Górnikowska, Aleksandra Dębowska, Mateusz Jędrusik, Damian Koclęga

\title{
Annealing effect on microstructure and chemical composition of Inconel 625 alloy
}

\section{Wpływ wyżarzania na mikrostrukturę i skład chemiczny stopu Inconel 625}

\begin{abstract}
Our research focused on Inconel 625 weld overlays on $16 \mathrm{Mo} 3$ steel boiler pipes. The investigation focused on the characterization of changes in the microstructure and chemical composition after annealing. The annealing was performed for ten hours at temperatures from 600 to $1000^{\circ} \mathrm{C}$. Changes in the microstructure were observed with a scanning and transmission electron microscope (SEM and TEM). The investigation was supplemented by hardness measurements.
\end{abstract}

Keywords: Inconel 625, microsegregation, annealing

\section{Streszczenie}

Badania przeprowadzono na napoinach ze stopu Inconel 625 na stali kotłowej 16Mo3. Skoncentrowano się na charakterystyce mikrostruktury i składu chemicznego zmian po wyżarzaniu. Obróbkę cieplną przeprowadzono w temperaturze od 600 do $1000^{\circ} \mathrm{C}$ przez 10 godzin. Zmiany mikrostruktury obserwowano przy użyciu skaningowej i transmisyjnej mikroskopii elektronowej (SEM i TEM). Badania zostały uzupełnione o pomiary twardości.

Słowa kluczowe: Inconel 625, mikrosegregacja, wyżarzanie

\section{Introduction}

Nickel alloys are widely used in various domains. These alloys have good strength properties at high temperatures (even with variable loads) and good resistance to creep and high temperature corrosion. These alloys can be used at cryogenic temperatures and temperatures of up to $1250^{\circ} \mathrm{C}$ (even $1400^{\circ} \mathrm{C}$ for short periods of activity) and in highly corrosive environments (compounds of sulfur, nitrogen, and carbon). With the appropriate alloying additions, these alloys provide useful corrosion resistance and have applications

Paweł Petrzak, Kazimierz Kowalski, Magdalena Rozmus-Górnikowska, Aleksandra Dębowska, Mateusz Jędrusik, Damian Koclęga: AGH University of Science and Technology, Faculty of Metal Engineering and Industrial Computer Science, Krakow, Poland; ppetrzak@agh.edu.pl 
in a wide range of industries [1,2]. Nickel is capable of dissolving high concentrations of alloying elements as compared to other metals, which creates the conditions not only to obtain specific properties of these alloys but also enabling them to be solid-solution strengthened $[3,4]$.

The high concentration of alloying elements in nickel alloys when the multicomponent phase equilibrium systems of nickel alloys are not known may, under come conditions, trigger phase transitions. A considerable concentration of elements such as Mo and $\mathrm{Nb}$ as well as the fact that padding welds have a cast structure that is characterized by a marked chemical composition inhomogeneity make the Inconel 625 alloy (which is a solution hardened alloy) prone to forming numerous precipitates within it $[5,6]$. The 625 alloy (which is designed as a single-phase alloy) actually proves to be very complex in terms of microstructure, especially under the prolonged influence of temperature $[7,8]$. This may result in the creation of a wide variety of secondary phases.

\section{Methodology}

The research was focused on Inconel 625 weld overlays on $16 \mathrm{Mo} 3$ steel boiler pipes. The investigation focused on the characterization of the changes in the microstructure and chemical composition after annealing. Particular emphasis was placed on the changes in the chemical composition across the fusion line as well as microsegregation. The annealing was performed for ten hours at temperatures from 600 to $1000^{\circ} \mathrm{C}$.

The microstructures were examined by a scanning electron microscope (SEM) model FEl Inspect S50, Nova NanoSEM 450, equipped with an energy dispersive X-ray spectroscopy (EDS) system. The samples for characterization by transmission electron microscopy (TEM) were produced and analyzed using a JEOL JEM-2010 microscope coupled with the EDS microanalysis system.

The investigation was supplemented by hardness measurements. The hardness measurements were performed on a Tukon 2500 Wolpert-Wilson with a Vickers indenter. The measurements were performed in a direction perpendicular to the fusion boundary as a function of the distance from the boundary. The process parameters were as follows: indenter load $-9.81 \mathrm{~N}$; time $-10 \mathrm{~s}$.

The samples for research were delivered by SEFAKO - a company specializing in the production of boilers. The weld overlays were produced by an innovative method of cold metal transfer (CMT).

\section{Results and discussion}

The typical microstructure revealed on an overlay cross-section is shown in Figure 1. Neither the fusion zone nor the entire overlay showed evidence of spatter, porosity, or 
microcracking. The Inconel overlay thickness was almost uniform, with a thickness of about $2.5 \mathrm{~mm}$. Its microstructure in regions adjoining the fusion zone exhibited a roughly columnar dendrite and cell structure emanating in a direction parallel to the heat extraction. In general, the microstructure of the overlay is a typical one for conventional casting $[9,10]$.

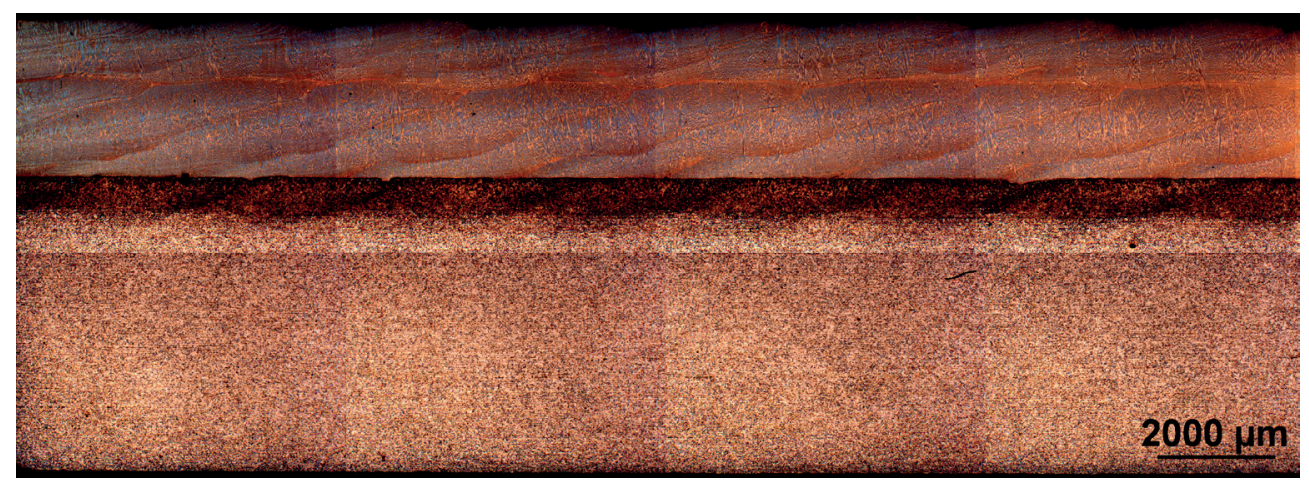

Fig. 1. Macrostructure of clad layer of Inconel 625 alloy

The dendrites form a tightly packed columnar-grain structure with precipitates in the inter-dendritic spaces enriched with $\mathrm{Nb}$ and Mo. At the same time, the content of $\mathrm{Cr}$ and $\mathrm{Ni}$ in the dendrite axes center is higher than average. The precipitates form in the interdendritic spaces due to an eutectic reaction after the liquid becomes enriched with Mo and Nb. The solidification process proceeds as follows: $L \rightarrow L+\gamma \rightarrow L+\gamma+\mathrm{NbC} \rightarrow$ $\mathrm{L}+\gamma+\mathrm{NbC}+$ Laves phase $\rightarrow \gamma+\mathrm{NbC}+$ Laves phase $[1,2,11]$.

In the as-welded condition, two types of precipitates were identified. The first type of precipitate is probably the Laves phase enriched with $\mathrm{Nb}$ and Mo. Their shape is elongated and thin. The second type consists of carbides enriched with $\mathrm{Nb}$ and $\mathrm{Ti}$, which have an angular shape. The shapes and chemical compositions of the precipitates are shown in Table 1 and Figure 2.

Table 1. Chemical composition of $\gamma$ phase, MC carbide, and Laves phase in weld overlay

\begin{tabular}{|l|c|c|c|c|c|c|}
\hline \multirow{2}{*}{ Phase } & \multicolumn{7}{|c|}{ Elements composition [wt.\%] } \\
\cline { 2 - 7 } & Nb & Mo & Cr & Fe & Ni & Ti \\
\hline$\gamma$ & 4 & 9 & 23 & 1 & 65 & - \\
\hline MC carbide & 56 & 4 & 6 & 1 & 10 & 15 \\
\hline Laves phase & 25 & 15 & 19 & 1 & 51 & - \\
\hline
\end{tabular}


a)

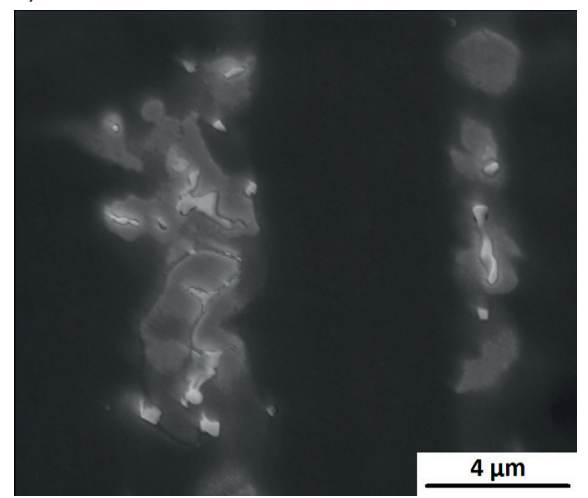

b)

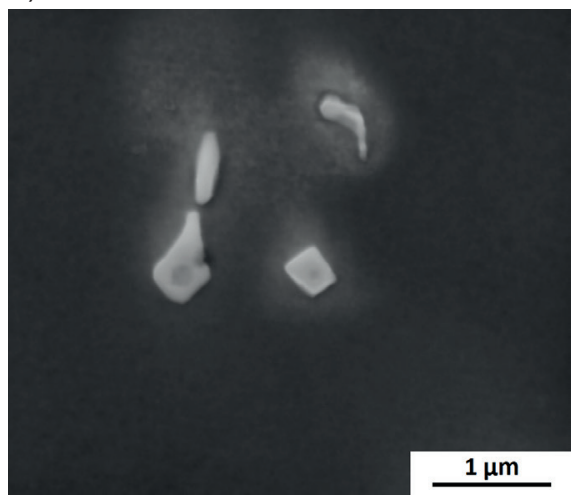

c)

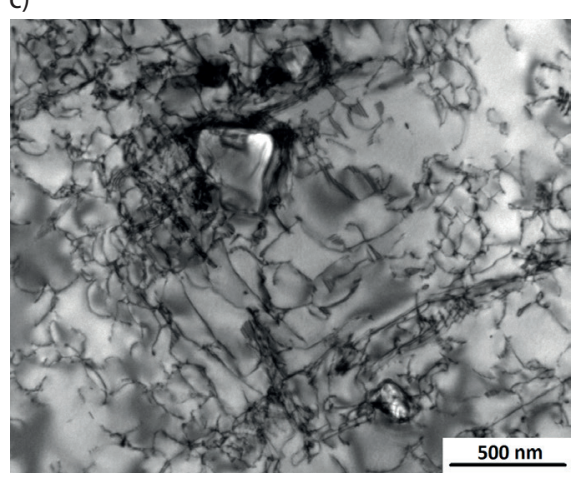

Fig. 2. SEM and TEM images of precipitates observed in Inconel 625 overlay: $(a, b)$ SEM of Laves phase and carbide; c) BF-TEM of carbide

After a heat treatment of between 600 and $700^{\circ} \mathrm{C}$, no changes were observed in the microstructure. It was found that, above $750^{\circ} \mathrm{C}$, the secondary phase dissolves and a new phase forms (needle-type form). The morphology of the needle-type form phase are 
shown in Figures $3 \mathrm{a}$ and $3 \mathrm{~b}$. Considering the particle shape and chemical composition, the data presented in references $[7,8]$ were identified as the $\delta$ phase. It was found that the $\delta$ phase is enriched with $\mathrm{Nb}(26 \mathrm{wt} . \%)$ and $\mathrm{Mo}(14 \mathrm{wt} . \%)$. After annealing at $1000^{\circ} \mathrm{C}$ (Fig. 3c), the needles observed previously in the interdendritic spaces disappeared.

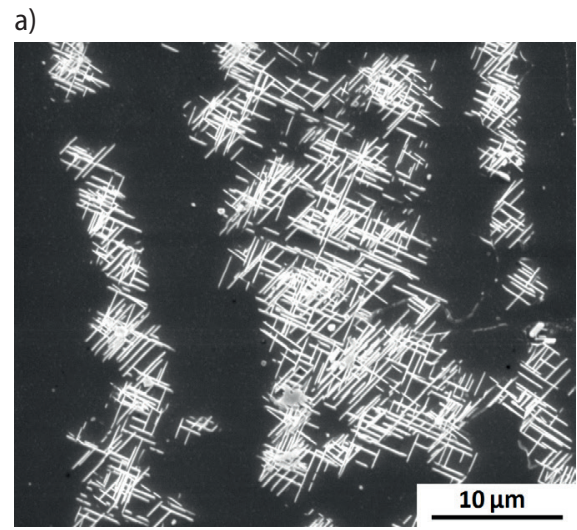

b)

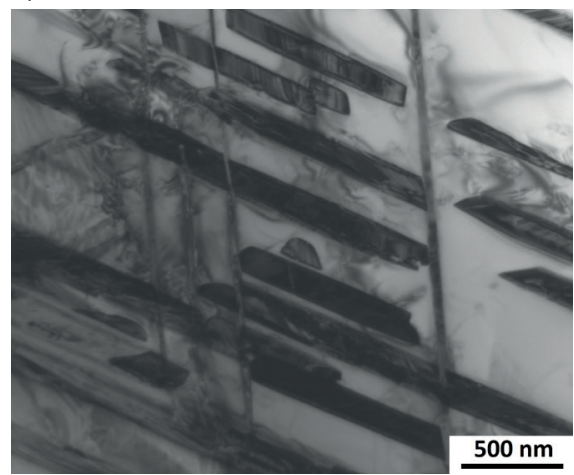

c)

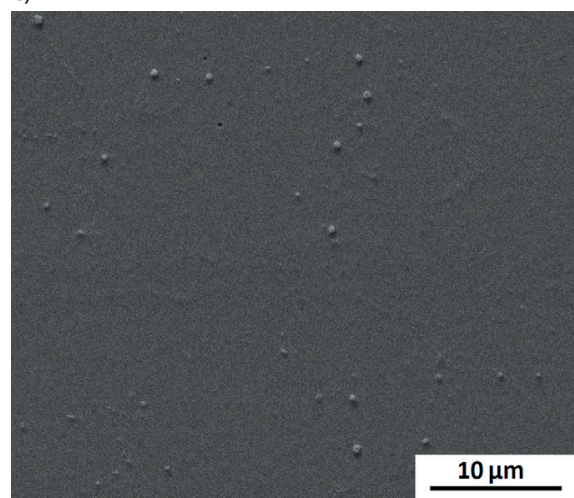

Fig. 3. Microstructure after annealing: a) $800^{\circ} \mathrm{C}$ (SEM); b) $800^{\circ} \mathrm{C}$ (BF-TEM); c) $1000^{\circ} \mathrm{C}$ (SEM) 
a)
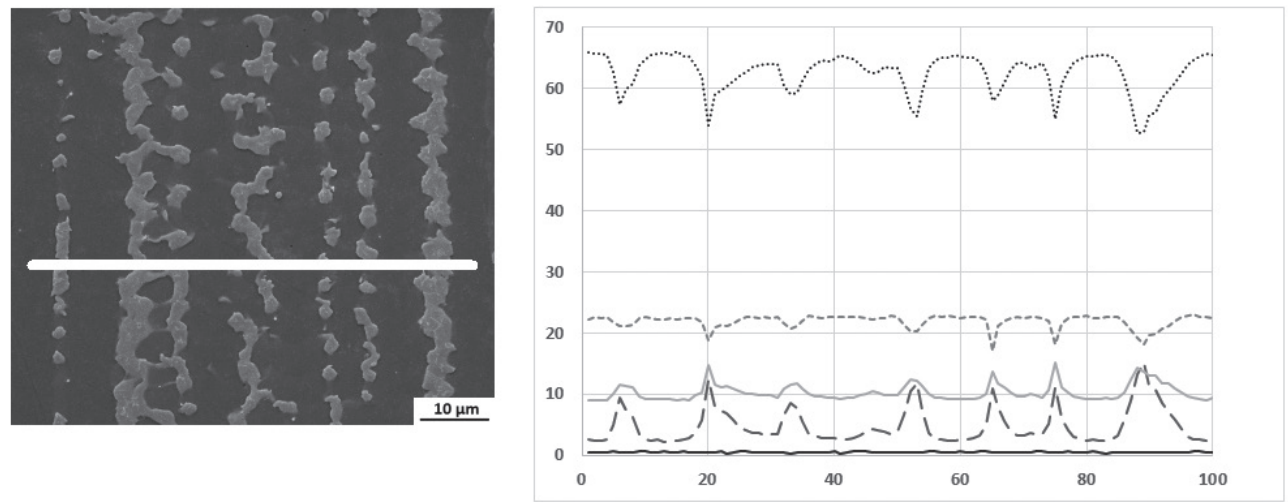

b)
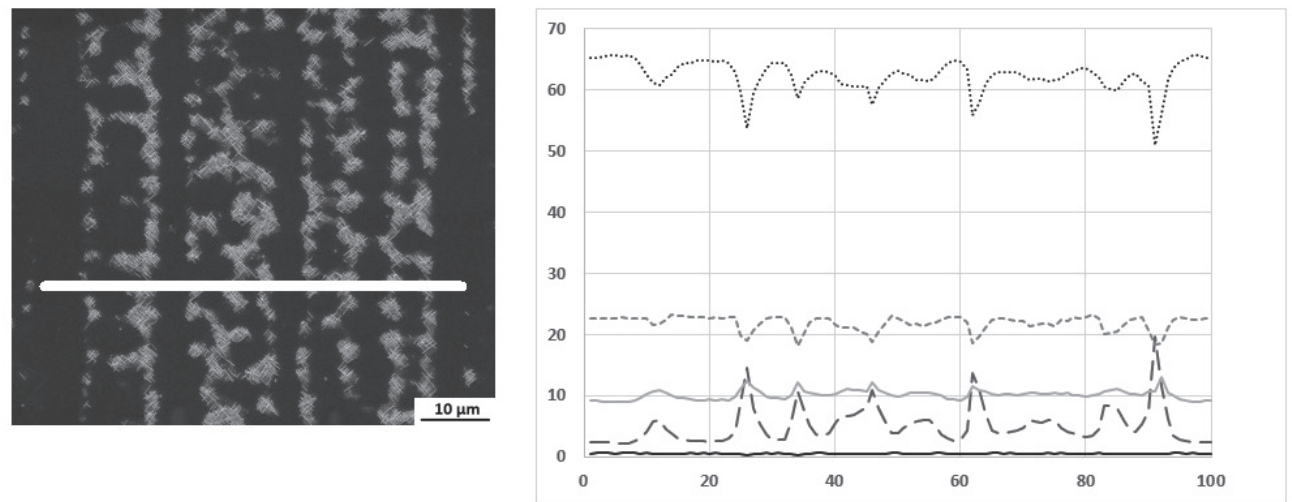

c)
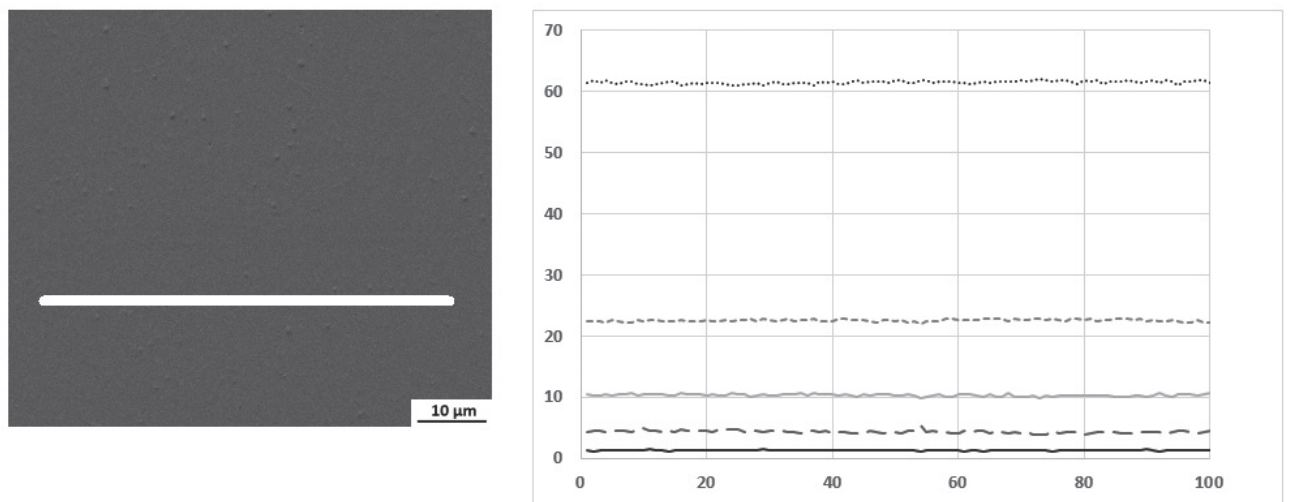

Fig. 4. Line distribution of chemical elements in weld overlay: a) as-welded condition; b) $800^{\circ} \mathrm{C}$; c) $1000^{\circ} \mathrm{C}$ 
Figure 4 shows the weld overlay microstructure with a marked line on which an analysis of the chemical composition was carried out. This allows for the assessment of microsegregation elements during the solidification process. An analysis of the chemical composition (the as-welded condition and after annealing at $800^{\circ} \mathrm{C}$ ) showed that the interdendritic regions were considerably enriched with $\mathrm{Nb}$ and Mo, simultaneously depleted of $\mathrm{Cr}$ and $\mathrm{Ni}$. The distribution of Fe in the weld overlay was relatively uniform. After annealing at $1000^{\circ} \mathrm{C}$, no differences in the chemical composition were found between the dendrite cores and the interdendritic spaces.

The hardness (Fig. 5) after welding was within a range of 250-275 HV1. After annealing at $600^{\circ}$ and $700^{\circ} \mathrm{C}$, an increased hardness occurs (exceeding a value of $300 \mathrm{HV} 1$ ). While at higher temperatures, there was a rapid decrease to about $225 \mathrm{HV} 1$. This is probably related to the phase transformations occurring in the interdendritic spaces.

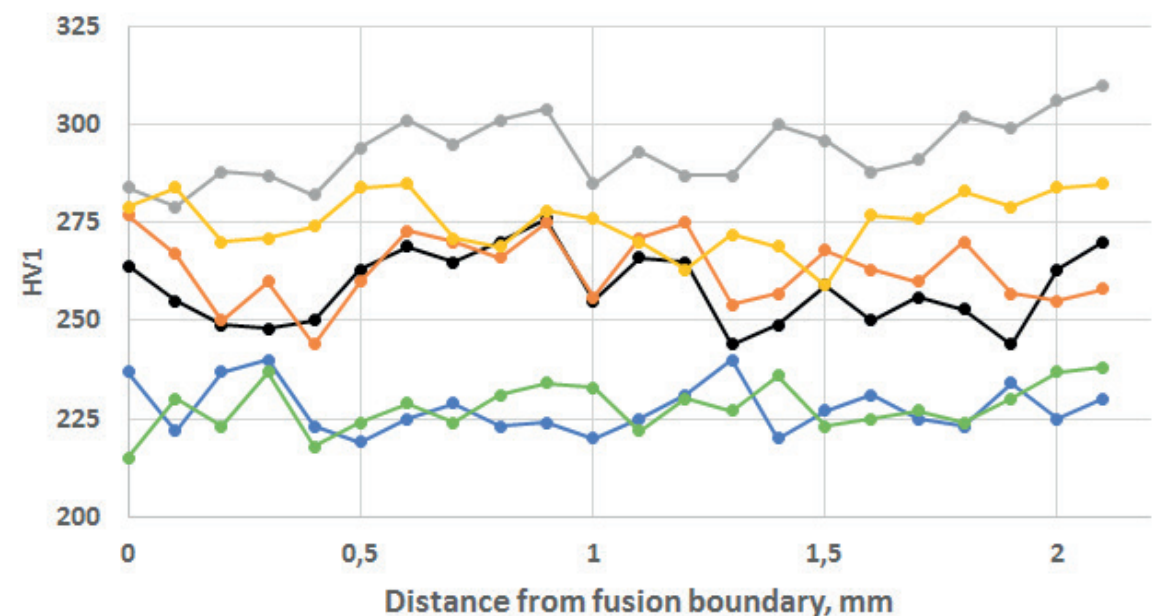

$\rightarrow$ as-welded condition $\rightarrow-600^{\circ} \mathrm{C} \rightarrow-700^{\circ} \mathrm{C} \rightarrow-800^{\circ} \mathrm{C} \rightarrow-900^{\circ} \mathrm{C} \rightarrow-1000^{\circ} \mathrm{C}$

Fig. 5. Hardness distribution in weld overlay

\section{Conclusion}

The microstructure of the weld overlay revealed a characteristic dendritic structure. The solidification process resulted in pronounced differences in the chemical composition between the dendrite cores and interdendritic spaces. An analysis of the chemical composition showed that the interdendritic regions were considerably enriched with $\mathrm{Nb}$ and Mo and simultaneously depleted of $\mathrm{Cr}$ and Ni. Despite the fact that Inconel 625 is a solidsolution strengthened alloy, the precipitates of the secondary phases occurs in the weld 
overlays. The microstructure depended on the annealing temperature. In the as-welded condition, two types of precipitates were identified. Analyzing the chemical composition and shape, these precipitates were identified as the Laves phase enriched with $\mathrm{Nb}$ and Mo and carbides enriched with $\mathrm{Nb}$ and $\mathrm{Ti}$. Above $750^{\circ} \mathrm{C}$, the secondary phase dissolves, and a new phase forms. Considering the particle shape and chemical composition, it was identified as the $\delta$ phase.

\section{Acknowledgements}

The present work was supported by the Ministry of Science and Higher Education of Poland under contract No. 11.11.110.295.

\section{References}

[1] DuPont J.N., Lippold J.C., Kiser S.D.: Welding metallurgy and weldability of nickel-base alloys. John Villey \& Sons, New Jersey 2009

[2] DuPont J.N.: Solidification of an Alloy 625 Weld Overlay. Metallurgical and Materials Transactions A, 27, 11 (1996), 3612-3620

[3] Banovic S.W., DuPont J.N., Marder A.R.: Dilution and microsegregation in dissimilar metal weld between upper austenitic stainless and nickel base alloys. Science and Technology of Welding and Joining, 7, 6 (2002), 374-383

[4] Adamiec J.: High temperature corrosion of power boiler components cladded with nickel alloys. Materials Characterization, 60 (2009), 1093-1099

[5] Rozmus-Górnikowska M., Blicharski M., Kusiński J., Kusiński L., Marszycki M.: Influence of boiler pipe cladding techniques on their microstructure and properties. Archives of Metallurgy and Materials, 58 (2013), 1093-1096

[6] Guo Qingmiao, Li Defu, Peng Haijian, Guo Shengli, Hu Jie, Du Peng: Nucleation mechanisms of dynamic recrystallization in Inconel 625 superalloy deformed with different strain rates. Rare Metals, 31, 3 (2012), 215-220

[7] Cortial F., Corrieu J.M., Vernot-Loier C.: Influence of heat treatment on microstructure, mechanical properties and corrosion resistance of weld alloy 625 . Metallurgical and Materials Transactions A, 26, 5 (1995), 1273-1286

[8] Mathew M.D., Parameswaran P., Bhanu Sankara Rao K.: Microstructural changes in alloy 625 during high temperature creep. Materials Characterization, 59 (2008), 508-513

[9] Tawancy H.M., Allam N.M.: Effect of $\mathrm{Ni}_{3} \mathrm{Nb}$ precipitation on the corrosion resistance of Inconel alloy 625 . Journal of Materials Science Letters, 9, 3 (1990), 343-347

[10] Shankar V., Bhanu Sankara Rao K., Mannan S.L.: Microstructure and mechanical properties of Inconel 625 superalloy. Journal of Nuclear Materials, 288 (2001), 222-232

[11] Cieslak M.J.: The metallurgy of alloy 625. Superalloys 718, 625 and Various Derivatives. The Minerals, Metals and Materials Society, Pennsylvania 1991 